\title{
THE RELATION BETWEEN PHYSICAL CONSTITUTION AND THE INCIDENCE OF DISEASE
}

\author{
The Disease Groups Include Peptic Ulcer, Cholecystitis and \\ Diabetes Mellitus
}

\author{
By J. FEIGENBAUM and DAVID HOWAT* \\ (From the Department of Medicine, Royal Victoria Hospital, Montreal)
}

(Received for publication September 30, 1933)

\section{HISTORICAL SUMMARY}

The problem associating constitution with the occurrence of disease in individuals is a very old one. It is probably as old as the study of disease itself, and its importance must have become impressed upon the minds of men investigating disease from the earliest times. Scrutiny of the Hippocratic writings (460 B.C. -375 B.C.), however, does not reveal any definite allusion to the relation between constitution and disease, although there are vague hints that these two elements are related in Hippocrates' mind. Any direct reference to this subject is likewise lacking in Galen's work (A.D. 130-200). Avicenna (circ. A.D. 980-1037) in his Canon does make numerous allusions to the importance of a recognition of the "temperament" in the study of character and in defining certain functions in an individual, but he does not correlate form with disease. The following sentences are worth quoting inasmuch as they indicate the status which the study of constitution had reached about A.D. 1000, a rather uncertain period in medical scientific history (1). "The external configuration of the body, including the physiognomy, is a reflection of the functional capacity of the internal organs and general make-up of the individual. The character, talents, physical form, shape of individual features, general development and indeed every detail of the physique, length of limbs, of fingers, cutaneous markings, contour of the eyes and ears etc., are all part and parcel with the functional conformation of the viscera and the mental characters." An interesting opinion on the relation between function and form is provided by Walkington in the "Optick Glasse of Humors" (1663). This author takes great pains to point out all the information that can be gained by physiognomical study. In this respect Walkington may be regarded as a precursor to that psychiatric school which links up certain constitutional types with psychiatric disease. The great clinical teachers Sydenham (1624-1689) and Boerhaave (1668-1738) did not add any new contributions to the subject.

There was renewed awakening of interest in the problem at the beginning of the nineteenth century, with an enthusiasm which was sustained until Pasteur's bacteriologic work eclipsed all else for the time in medicine. A rich literature grew up on the continent, while the group of celebrated English clinicians of the nineteenth century left some lasting contributions. Jonathan Hutchinson was perhaps the keenest student of constitution in this group. He possessed a wide background of clinical training, and he could therefore draw upon this experi-

* Assistant Professor of Mathematics, McGill University, Montreal. 
ence in arriving at his conclusions. Although Hutchinson is often cited as an authority who pointed towards the close relationship between constitution and certain diseases, actually study of his work discloses that he was skeptical as to the existence of such a relationship. In "The Pedigree of Disease" (6) Hutchinson points out in quite a modern fashion the difficulties inherent in a study of constitution. "He (the student of constitution) will discover that he is mistaking for criteria of temperament conditions which are simply indicative of youth, ${ }^{1}$ or age, or health or disease, or the effects of past anxiety and trouble. ... So should the student of temperament scrupulously reject all that has been superadded and is in a sense accidental. . . . Indeed it may be questioned whether in a large majority of cases there do really exist in persons as yet in perfect health any peculiarities by which we can predicate or discriminate the

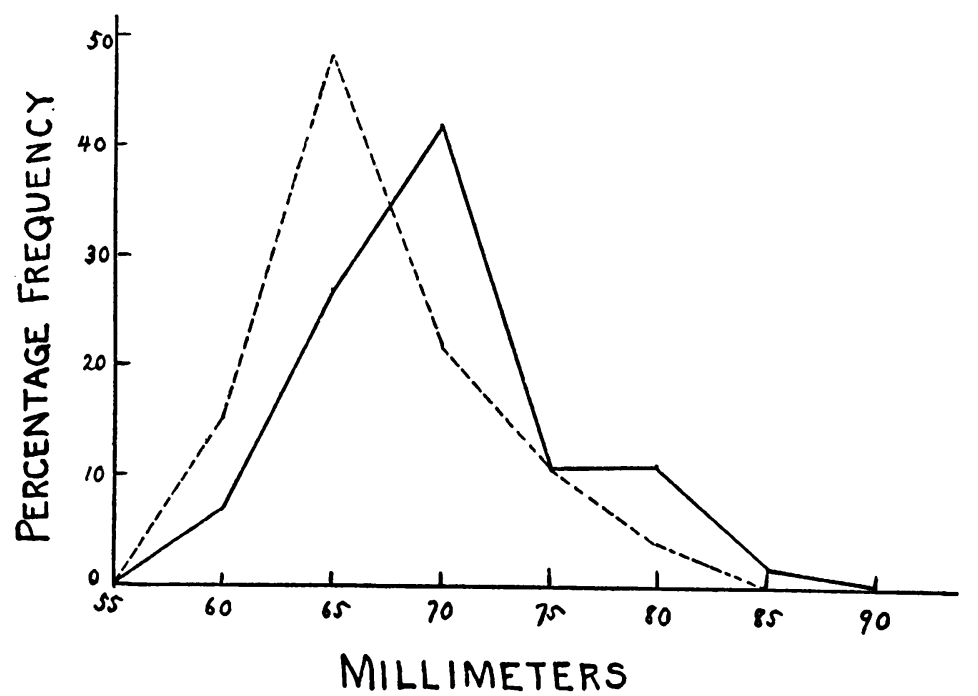

FIG. 1

Nasion prosthion (male).

Peptic ulcer cases 55 ;

Diabetic cases 27 . Note $(a)$ the peak of the ulcer patients at 70 millimeters and the peak for the diabetics at 65 millimeters, $(b)$ the very considerable area of overlapping which may be seen in almost each one of the curves. In this instance ' $t$ ' was significant.

' fundamental mode of vital activity (constitution)'." Furthermore, he shrewdly called attention to the importance of race as a factor which might easily interfere with the correct interpretation of any results obtained in a study of constitution.

For a period of 50 or 60 years following Pasteur's initial endeavours, the study of constitution was neglected, but interest in it was revived once more at the beginning of the present century. The reason for this was that the available bacteriological knowledge was found inadequate to explain many of the phenomena of disease so that interest shifted from micro-organisms to man himself. Most prominent in the recent investigation of constitution have been

1 Italics our own. 
Bauer (12), Kretschmer (13), di Giovanni (15), Stockard (8) and Draper (5). Draper has been one of the most conspicuous workers in this field. Moreover, he deserves much of the credit for applying exact mathematical methods to the investigation of a problem which in the past was approached from the point of view of indefinite clinical impressions. In the present work we have pursued Draper's suggestions insofar as the anthropometric measurements are concerned.

THE PROBLEM AND THE METHODS EMPLOYED

Constitution may be defined as the sum total of native or acquired characteristics by virtue of which the individual is rendered more or less susceptible to disease. Most of the confusion in the study of constitution has arisen because of the failure to divide the subject into its component parts,

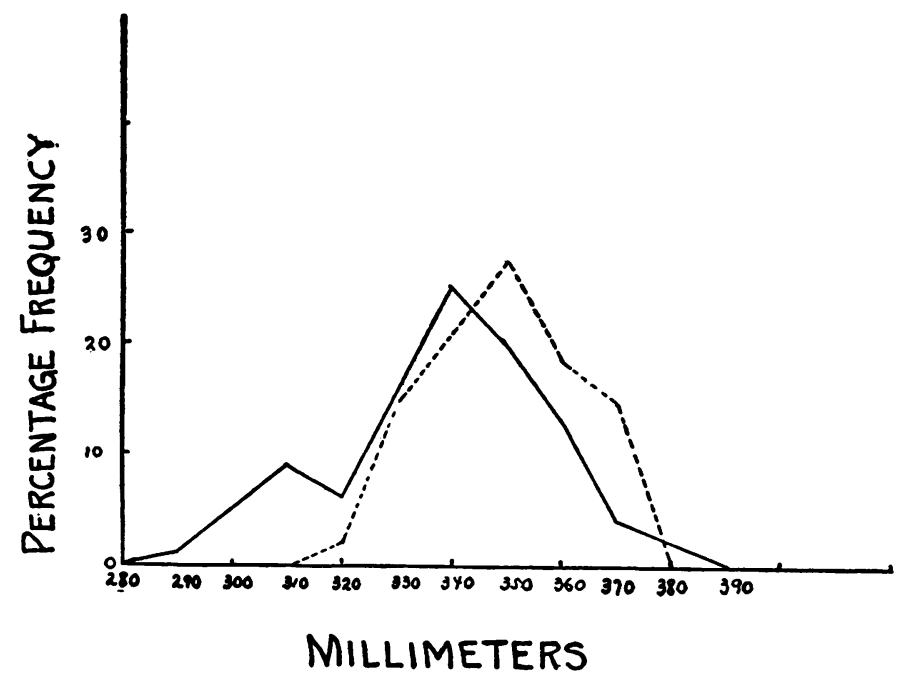

FIG. 2

Neck circumference (male). - Peptic ulcer cases 55; - - Diabetic cases 27 . The peptic ulcer curve is skewed to the left, indicating that the neck circumference in this disease group is smaller than in the diabetic patients.

to reach a sound conclusion regarding each of these parts, and then to correlate all the phases of the subject. If the problem were attacked from the point of view of each constituent phase, one would then be prepared to decide how constitution may affect the incidence of disease in man. Draper has divided human constitution so far as it relates to disease into four parts-the anatomical, physiological, immunological and psychological panels. His early work dealt with the first of these panels, and the present work has been restricted to this field. It is this aspect of constitution which caught the fancy of clinicians through the ages. It is this aspect also which lends itself, in many ways at least, to more or less accurate methods of 
study. It should be emphasized however, that a negative result in the anatomical panel does not invalidate the observations that man and animals show a predisposition or an immunity to certain diseases. Failure to obtain confirmation of this fact by a careful study of the external configuration of the body indicates only that an old clinical theory is not founded on actual fact.

The problem presented by an investigation of the anatomical panel simply stated appears to be this-will an individual of a given complexion with certain body measurements and proportions be especially predisposed to the development of a specified disease? The difficulties encountered

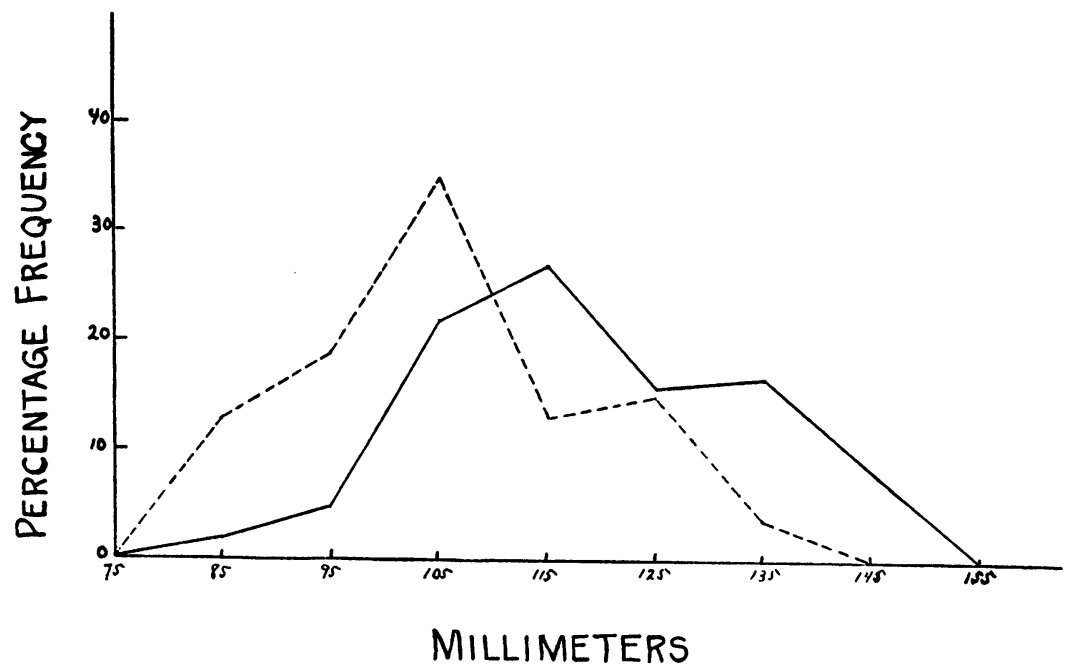

FIG. 3

Neck length (male).

Peptic ulcer cases 55;

Diabetic cases 26. Note the relatively small area of overlapping in this figure. Statistical treatment of the data involved showed a well marked tendency for peptic ulcer males to display a longer neck; ' $t$ ' in this case was 3.8 , almost twice the limit of significance. It is in a case of this kind that the relative frequency curve suggests the actual state of affairs.

in working out this problem are as follows. Firstly, one must be reasonably sure that certain body proportions are not caused by disease. For this reason we have avoided selecting diseases which are characterized especially by cachexia. Furthermore, most of the measurements which have been taken are those of the distances between bony points, and disease except in unusual instances would be unlikely to affect these.

Secondly, the racial factor is a very important one in evaluating the importance of the physical constitution. However, as will be seen, the racial distribution of the cases did not affect our results significantly. In the present discussion of race, it was not possible to divide patients as be- 
longing to the ethnologic groups typified by the Alpine, Mediterranean, Scandinavian and Slav races. The most that could be done was to record and note the country of birth of each patient and employ this in the loose sense of "race." In the three large disease groups there was no predominance of one or other racial type, but each group showed approximately the same mixture of races as did the other. Thus in the male diabetic, peptic ulcer, and cholecystitis groups, the greatest percentage was of $\mathrm{Ca}$ nadian birth (Table I). In the diabetic female group also, those of Ca-

TABLE I

Racial distribution of disease groups

Percentages

\begin{tabular}{|c|c|c|c|c|c|c|}
\hline Racial types & $\begin{array}{c}\text { Dia- } \\
\text { betes. } \\
\text { male }\end{array}$ & $\begin{array}{l}\text { Peptic } \\
\text { ulcer, } \\
\text { male }\end{array}$ & $\begin{array}{l}\text { Chole- } \\
\text { cystitis, } \\
\text { male** }\end{array}$ & $\begin{array}{c}\text { Dia- } \\
\text { betes, } \\
\text { female }\end{array}$ & $\begin{array}{l}\text { Peptic } \\
\text { ulcer, } \\
\text { female }\end{array}$ & $\begin{array}{l}\text { Chole- } \\
\text { cystitis, } \\
\text { female }\end{array}$ \\
\hline & per cent & per cent & per cent & per cent & per cent & per cent \\
\hline Canadian. & 51 & 23 & 44 & 29 & 25 & 14 \\
\hline English. . & 8 & 17 & 22 & 8 & 33 & 14 \\
\hline Scottish. & $\mathbf{0}$ & 16 & 0 & $\mathbf{0}$ & 17 & 5 \\
\hline Irish $\ldots \ldots \ldots \ldots$ & 8 & 3 & $\mathbf{0}$ & $\mathbf{0}$ & $\mathbf{0}$ & $\mathbf{0}$ \\
\hline Russian Jewish. & 15 & 5 & 22 & 31 & 17 & 24 \\
\hline Polish Jev & 0 & 17 & 0 & 6 & 0 & 11 \\
\hline Roumanian Jewish. & 8 & 3 & 12 & 11 & $\mathbf{0}$ & 3 \\
\hline Slav.... & $\mathbf{0}$ & 9 & 0 & 2 & $\mathbf{0}$ & 5 \\
\hline French Canadian. & 7 & $\mathbf{0}$ & $\mathbf{0}$ & 6 & $\mathbf{0}$ & 16 \\
\hline American......... & $\mathbf{0}$ & 2 & 0 & 3 & $\mathbf{0}$ & 3 \\
\hline Med & $\mathbf{0}$ & 2 & $\mathbf{0}$ & 2 & $\mathbf{0}$ & 5 \\
\hline Miscellaneous. & 3 & 3 & 0 & 2 & 13 & 0 \\
\hline
\end{tabular}

* Total, 9 cases.

† Total, 12 cases.

nadian origin were second only to those of Russian birth. Again, although in the female peptic ulcer and cholecystitis groups native English and Russians predominated, nevertheless, Canadians constituted a relatively high percentage. The ideal condition, of course, would be to select individuals of the disease groups from a single pure race. Unfortunately, such a selection would be almost impossible in Canada, and it would be very difficult of realization even in Europe.

A third factor which must be borne in mind, and for which allowance should be made, is the discrepancy in results which may appear because of a difference in the number of individuals in the various disease groups (Table II). It will be evident that the number of cases in two of the disease entities was small. There were 9 patients in the male cholecystitis group, and 12 patients in the female peptic ulcer group. However by the statistical treatment of the figures this difficulty was overcome in part at least. In the review of the figures, those errors which were due to " sample 
TABLE II

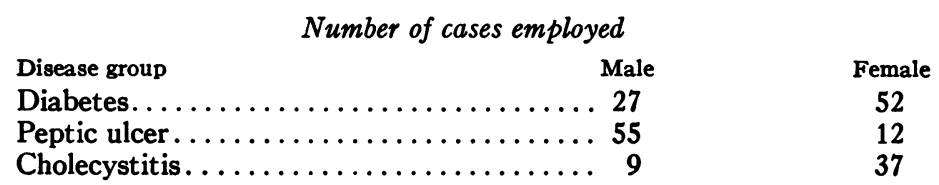

differences," that is discrepancies which occurred because of the employment of groups of small size, usually could be differentiated from actual differences.

Particular care was exercised in the selection of cases, so that only those patients in whom the diagnosis was certain were used in the work. In the case of diabetics, the presence of symptoms with hyperglycemia and glycosuria were the criteria of diagnosis. Practically all the patients in the cholecystitis group showed cholecystitis with cholelithiasis at operation before being included in the series. The large majority of patients in the peptic ulcer group showed corroboration of the diagnosis by operation. In a few, the diagnosis was made by a combination of the clinical picture and the roentgenographic findings.

The actual anthropometric work was carried out by one person ( $J$. F.), so that the important source of error which may arise in work of this kind as a result of the personal equation, was eliminated. As already stated, we followed in broad outline Draper's methods, although the number of measurements was reduced considerably and usually the distance between bony points was preferred. It was not always possible to be certain that the anthropological points selected in this work coincided precisely with Draper's, and this probably accounts for many of the more striking differences in our results. Altogether, 37 measurements were taken on each patient, in addition to notes regarding the individual's complexion, distribution of hair, colour of the iris, and presence or absence of freckles, but only the anthropological measurements will be considered at this time. Table III indicates how the various measurements were obtained.

The lower age limit decided upon for the statistics studied was 21 years, because most of the bones have ceased growing by this time. Table IV indicates the average age of the individual disease groups. It will be noted that the greatest difference between any two groups is 11.5 years. Moreover this difference occurs in the fifth decade of life, so that its significance, so far as anthropometric data is concerned, is very slight.

So far as the application of the statistical method to the work is concerned, certain well-defined rules were followed. The mean (or average) was first obtained for each of the groups. The difference between the means was then obtained, and the standard error of this difference determined. Where the difference between the means was equal to or exceeded twice the standard error, the ratio (indicated in this paper by the letter " $t$ ") was regarded as significant. That difference then may be expressed 
TABLE III

Anatomic points used to obtain measurements

Facial diameter: Distance between the most prominent points of origin of maxillary ridges.

Nasion prosthion: Distance between bridge of nose and interval between incisors.

Ear width: From the tip of the tragus to the outermost part of the ear.

Ear length: From the tip of the lobe to the uppermost part of the helix.

Ascending ramus length: From the angle of the mandible to the tip of the coranoid process.

Horizontal ramus length: From the angle of the mandible to the symphysis.

Bigonial diameter: The distance between both angles of the mandible.

Inter-pupillary space: The distance between the center of each pupil, with the patient looking straight ahead.

Palpebral breadth: The distance between the free margin of the lids with the patient looking straight ahead.

Palpebral length: The length of the free margin of the lids, with the eyes shut.

Cephalic length: The distance between the occiput and the most prominent part of the glabella as obtained by a cephalometer in the mid-sagittal plane.

Cephalic breadth: The distance between the most prominent parts of the parietal bones as measured by a cephalometer, at right angles to the mid-sagittal plane.

Nasion submenton: The distance between the bridge of the nose, and the under surface of the symphysis of the mandible.

Neck circumference: Circumference at the base of the neck.

Neck length: Distance between episternal notch and the junction between the neck and chin, as measured by a cephalometer.

Thoracic anteroposterior diameter: The antero-posterior diameter at the level of the 4th rib anteriorly.

Thoracic lateral diameter: The lateral diameter at the level of the 4th interspace anteriorly.

Bi-acromial diameter: The distance between the most prominent parts of the acromial processes.

Chest circumference: Circumference of the chest at level of the 4th interspace.

Chest length: Episternal notch to tip of manubrium.

Umbilicus-xiphoid: Distance between umbilicus and tip of xiphoid.

Umbilicus-pubis: Distance between umbilicus and the upper level of the symphysis pubis.

Bi-iliac diameter: Distance between anterior superior spines.

Nail length: Longitudinal diameter of nail bed.

Nail breadth: Transverse diameter of nail bed.

Hand length: Distance between the end of the radial styloid and the tip of the middle finger.

Hand breadth: The widest part of the palm.

Finger circumference: Circumference at the junction of first and second phalanges.

Leg circumference: At the middle of the lower leg.

Acromion to the lateral epicondyle of the humerus: Bony points as stated, giving length of humerus.

Lateral epicondyle of the humerus to the tip of radial styloid: Bony points as stated, giving length of radius.

Acromion to the tip of the middle finger: As stated.

Internal meniscus of the knee to the tip of tibia: As stated, giving length of tibia.

Great trochanter of the femur to the lateral meniscus: As stated, giving length of femur.

Great trochanter of the femur to the ground: Tip of the great trochanter to ground, giving total length of lower limb.

numerically by saying that the chances of an individual with such a body measurement falling into a certain disease group is twenty to one. This 
TABLE IV

Age distribution of disease groups

\begin{tabular}{|c|c|c|}
\hline Disease group & Sex & $\begin{array}{c}\text { Average age } \\
\text { years }\end{array}$ \\
\hline Diabetes. & Male & 49.5 \\
\hline Diabetes. . & Female & 52.3 \\
\hline Peptic ulcer. & Male & 43.2 \\
\hline Peptic ulcer. & Female & 44.1 \\
\hline Cholecystitis & Male & 52.7 \\
\hline Cholecystitis & Female & 40.8 \\
\hline
\end{tabular}

method of working out results is applicable to groups of 30 or over, and it can be applied with less certainty to smaller groups. The equation involved may be represented thus :

$$
\text { " } \mathrm{t} "=\frac{\text { difference of mean }}{\text { standard error of difference }}
$$

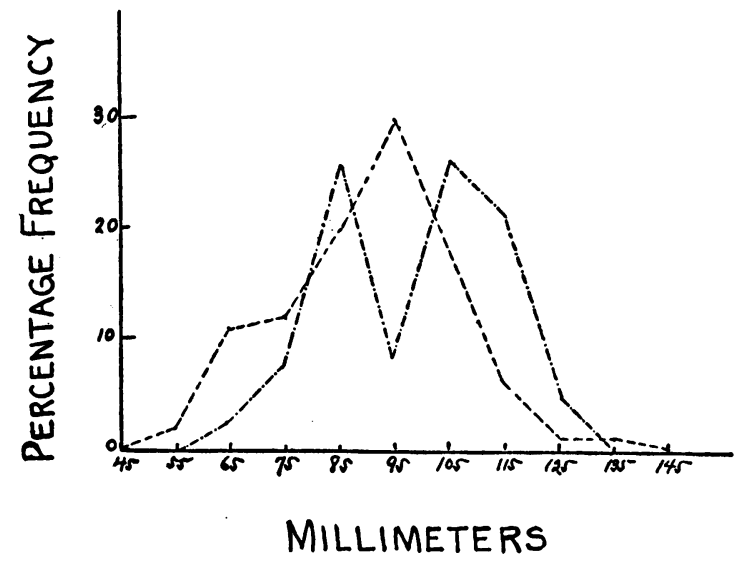

FIG. 4

Neck length (female). - - D Diabetic cases 52 ; - - - C Cholecystitis cases 37 . Note the irregularity of the cholecystitis curve. Such a curve indicates "sample errors," if the number of cases employed is small. It is not usual for two peaks to occur in the same curve in a biometric graph.

It was thought also that if the result obtained in this work were to be subjected to more critical analysis we would be much closer to the actual state of affairs. Consequently in evaluating the importance of " $t$ " only those differences were considered significant in which " $t$ " was 2 or higher in both the male and the female groups. Finally, it is important to emphasize the fact that in all this work, one is dealing with whole groups, so that the application of certain conclusions, which may be perfectly valid for groups, is hazardous when only one individual is concerned.

The graphic representation of statistical results in this as in other problems, although attractive, cannot be accepted as the final test of the statisti- 
cal method. Graphic figures are useful for creating a visual image of the distribution of certain numbers over a given range. However, when it becomes necessary to compare two or more sets of numbers, and to designate the importance of this comparison, then the graphic method fails. It is for this reason that relatively few graphs are presented here, and these only in the cases where " $t$ " was found to be significant. It was necessary in constructing graphs to choose one of several methods generally employed. Cumulative frequency curves have been used by other workers in this field. In the present work relative frequency curves were constructed largely because it was considered that they offer a more accurate representation of facts than do the cumulative curves. It is unfortunate that Draper's curves and ours cannot be compared because of the difference in the type of curve employed.

\section{RESULTS}

So far as the results are concerned, these have been set down in Table V. This table really constitutes a concise summary of the work presented inasmuch as in it are found the averages for each group, the differences between the averages, and the value for 270 of the measurements including 48 indices. Of the total number " $t$ " equalled or exceeded 2, in 53 instances, or 19 per cent. The difference observed in the nasion prosthion between the peptic ulcer and cholecystitis males in this series is not seen in Draper's figures. The bigonial diameter, the measurement which determines the lower facial width, is greater in both the male and female diabetic groups than in the peptic ulcer cases. This is one of the few examples of a difference occurring in the same direction and of significant degree in both the male and female members of the disease groups.

The neck length of the peptic ulcer male and female groups was definitely greater than in the diabetic patients, while a similar difference was observed in comparing the cholecystitis and the diabetic females.

The thoracic anteroposterior diameter was deeper in the diabetic than in the peptic ulcer groups, both with the males and the females. The same relationship was discovered to exist in the thoracic lateral diameter and in the chest circumference. And so it can be stated that the diabetic population has a deeper, a broader and a more voluminous chest than the peptic ulcer race.

The bi-acromial diameter of the peptic ulcer females was greater than the corresponding diameter of the cholecystitis group. Draper's figures showed an inverse relationship. In this case where the distance measured lay between bony points, the failure of these figures to corroborate those of Draper indicates that the association between a large bi-acromial diameter and peptic ulcer females is not a constant one, and that we are dealing here with a "sample error." On the other hand, the results in this and in Draper's series are comparable when applied to the chest circumference in 
TABLE $V$

Arithmetic means, difference of means, value of $t$

\begin{tabular}{|c|c|c|c|c|c|c|}
\hline $\begin{array}{c}\text { Part } \\
\text { measured }\end{array}$ & $\begin{array}{l}\text { Arith- } \\
\text { metic } \\
\text { mean, } \\
\text { M1: } \\
\text { Peptic } \\
\text { ulcers }\end{array}$ & $\begin{array}{l}\text { Arith- } \\
\text { metic } \\
\text { mean. } \\
\text { Ma. } \\
\text { Dia- } \\
\text { betics }\end{array}$ & $\begin{array}{l}\text { Arith- } \\
\text { metic } \\
\text { mean, } \\
\text { Ms. } \\
\text { Chole- } \\
\text { cystitis }\end{array}$ & $\begin{array}{c}\text { Difference } \\
\text { between } \\
\mathbf{M}_{1} \text { and } \mathbf{M}_{2} \\
\mathrm{t}_{1-3}\end{array}$ & $\begin{array}{c}\text { Difference } \\
\text { between } \\
\mathbf{M}_{\mathbf{1}} \text { and } \mathbf{M}_{\mathbf{2}} \\
\mathbf{t}_{\mathbf{1}} \mathbf{3}\end{array}$ & $\begin{array}{c}\text { Difference } \\
\text { between } \\
\mathbf{M}_{3} \text { and } \mathbf{M}_{2} \\
\mathbf{t}_{2}\end{array}$ \\
\hline $\begin{array}{l}\text { Facial diameter, } m m . \\
\mathbf{M} \ldots \ldots \ldots \ldots \ldots \ldots \ldots \ldots \\
\mathbf{F} \ldots \ldots \ldots \ldots \ldots \ldots\end{array}$ & $\begin{array}{l}110.5 \\
101.8\end{array}$ & $\begin{array}{l}111.8 \\
106.2\end{array}$ & $\begin{array}{l}112.1 \\
105.3\end{array}$ & $\begin{array}{l}-1.3 ; 0.8 \\
-4.4 ; 2.3\end{array}$ & $\begin{array}{l}-1.6 ; 0.7 \\
-3.5 ; 1.8\end{array}$ & $\begin{array}{l}-0.3 ; 0.07 \\
0.9 ; 0.6\end{array}$ \\
\hline $\begin{array}{l}\text { Nasion prosthion, } m m . \\
\quad \mathbf{M} \ldots \ldots \ldots \ldots \ldots \ldots \ldots \\
\mathrm{F} \ldots \ldots \ldots \ldots \ldots \ldots \ldots\end{array}$ & $\begin{array}{l}70.0 \\
62.8\end{array}$ & $\begin{array}{l}67.0 \\
62.0\end{array}$ & $\begin{array}{l}66.0 \\
63.9\end{array}$ & $\begin{array}{l}3.0 ; 2.4 \\
0.8 ; 0.4\end{array}$ & $\begin{array}{l}4.0 ; 2.1 \\
-1.1 ; 0.6\end{array}$ & $\begin{array}{l}1.0 ; 0.5 \\
-1.9 ; 1.7\end{array}$ \\
\hline 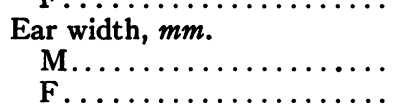 & $\begin{array}{l}29.4 \\
27.1\end{array}$ & $\begin{array}{l}29.1 \\
27.8\end{array}$ & $\begin{array}{l}28.1 \\
27.1\end{array}$ & $\begin{array}{l}0.3 ; 0.5 \\
-0.7 ; 0.7\end{array}$ & $\begin{array}{l}1.3 ; 1.4 \\
0.0 ; 0.0\end{array}$ & $\begin{array}{l}1.0 ; 0.8 \\
0.7 ; 1.1\end{array}$ \\
\hline $\begin{array}{l}\text { Ear length, } m m . \\
\quad \mathbf{M} \ldots \ldots \ldots \ldots \ldots \ldots \\
\mathrm{F} \\
\ldots \ldots \ldots \ldots \ldots \ldots\end{array}$ & $\begin{array}{l}66.6 \\
59.5\end{array}$ & $\begin{array}{l}66.7 \\
64.5\end{array}$ & $\begin{array}{l}68.8 \\
61.3\end{array}$ & $\begin{array}{l}-0.1 ; 0.1 \\
-5.0 ; 3.1\end{array}$ & $\begin{array}{l}-2.2 ; 1.4 \\
-1.8 ; 1.1\end{array}$ & $\begin{array}{l}-2.1 ; 1.2 \\
3.2 ; 2.8\end{array}$ \\
\hline 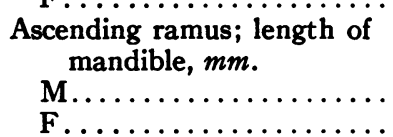 & $\begin{array}{l}55.0 \\
49.0\end{array}$ & $\begin{array}{l}56.8 \\
51.1\end{array}$ & $\begin{array}{l}58.5 \\
51.0\end{array}$ & $\begin{array}{l}-1.8 ; 1.2 \\
-2.1 ; 1.2\end{array}$ & $\begin{array}{l}-3.5 ; 1.6 \\
-2.0 ; 1.2\end{array}$ & $\begin{array}{l}-1.7 ; 0.6 \\
0.0 ; .04\end{array}$ \\
\hline $\begin{array}{l}\text { Horizontal ramus; length of } \\
\text { mandible, } m m \text {. }\end{array}$ & & & 31.0 & & & $0.0 ; .04$ \\
\hline 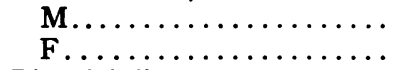 & $\begin{array}{l}94.2 \\
86.6\end{array}$ & $\begin{array}{l}94.5 \\
90.4\end{array}$ & $\begin{array}{l}97.6 \\
86.8\end{array}$ & $\begin{array}{l}-0.3 ; 0.2 \\
-3.8 ; 2.4\end{array}$ & $\begin{array}{l}-3.4 ; 1.7 \\
-0.2 ; 0.0\end{array}$ & $\begin{array}{l}-3.1 ; 1.3 \\
3.6 ; 2.8\end{array}$ \\
\hline $\begin{array}{l}\text { Bigonial diameter, } m m . \\
\quad \mathbf{M} . \ldots \ldots \ldots \ldots \ldots \ldots \ldots\end{array}$ & $\begin{array}{r}105.0 \\
98.4\end{array}$ & $\begin{array}{l}108.5 \\
102.8\end{array}$ & $\begin{array}{l}111.5 \\
101.5\end{array}$ & $\begin{array}{l}-3.5 \\
-4.4\end{array}$ & $-6.5 ; 3.3$ & $-3.0 ; 1.1$ \\
\hline 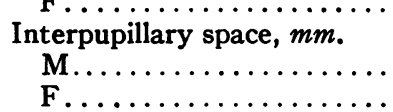 & $\begin{array}{l}64.0 \\
98.4\end{array}$ & $\begin{array}{r}63.9 \\
102.8\end{array}$ & $\begin{array}{r}101.5 \\
65.0 \\
101.5\end{array}$ & $\begin{array}{l}-4.4 ; 2.6 \\
0.09 ; 0.08 \\
4.4 ; 2.6\end{array}$ & $\begin{array}{l}-3.1 ; 1.6 \\
-0.9 ; 0.5 \\
-3.1 ; 1.6\end{array}$ & $\begin{array}{l}-1.0 ; 0.5 \\
1.3 ; 1.1\end{array}$ \\
\hline 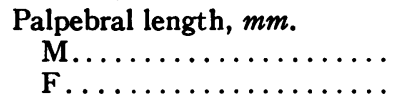 & $\begin{array}{l}27.8 \\
27.8\end{array}$ & $\begin{array}{l}28.2 \\
27.7\end{array}$ & $\begin{array}{l}27.2 \\
26.8\end{array}$ & $\begin{array}{l}-0.4 ; 0.3 \\
0.1 ; 0.05\end{array}$ & $\begin{array}{l}0.6 ; 0.4 \\
1.0 ; 0.8\end{array}$ & $\mid \begin{array}{l}1.0 ; 0.7 \\
0.9 ; 1.1\end{array}$ \\
\hline $\begin{array}{l}\text { Palpebral breadth, } m m . \\
\quad \mathbf{M} \ldots \ldots \ldots \ldots \ldots \ldots \ldots \\
\mathbf{F} \ldots \ldots \ldots \ldots \ldots \ldots\end{array}$ & $\begin{array}{r}10.7 \\
9.4\end{array}$ & $\begin{array}{r}10.0 \\
9.8\end{array}$ & $\begin{array}{l}10.3 \\
10.2\end{array}$ & $\mid \begin{array}{l}0.7 ; 1.4 \\
-0.4 ; 0.7\end{array}$ & $\mid \begin{array}{l}0.4 ; 0.5 \\
-0.8 ; 1.8\end{array}$ & $\begin{array}{l}-0.3 ; 0.4 \\
-0.4 ; 1.1\end{array}$ \\
\hline $\begin{array}{l}\text { Cephalic length, } m m . \\
\quad \mathbf{M}, \ldots \ldots \ldots \ldots \ldots \ldots \\
\mathrm{F} \ldots \ldots \ldots \ldots \ldots \ldots\end{array}$ & $\begin{array}{l}180.2 \\
174.0\end{array}$ & $\begin{array}{l}182.1 \\
173.1\end{array}$ & $\begin{array}{l}179.2 \\
172.5\end{array}$ & $\begin{array}{l}-1.9 ; 1.0 \\
0.9 ; 0.4\end{array}$ & $\begin{array}{l}1.0 ; 0.3 \\
1.5 ; 0.6\end{array}$ & $\mid \begin{array}{l}2.9 ; 1.0 \\
0.6 ; 0.3\end{array}$ \\
\hline 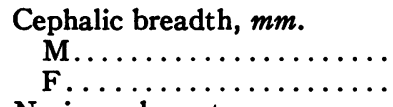 & $\begin{array}{l}143.6 \\
139.5\end{array}$ & $\begin{array}{l}145.2 \\
143.4\end{array}$ & $\begin{array}{l}145.4 \\
142.3\end{array}$ & $\begin{array}{l}-1.6 ; 1.0 \\
-3.9 ; 1.8\end{array}$ & $\begin{array}{l}-1.8 ; 0.7 \\
-2.8 ; 1.6\end{array}$ & $\begin{array}{l}-0.2 ; 0.0 \\
0.9 ; 0.6\end{array}$ \\
\hline $\begin{array}{l}\text { Nasion submenton, } m m \\
\mathbf{M} . \ldots \ldots \ldots \ldots \ldots \ldots \ldots \\
\mathrm{F} . \ldots \ldots \ldots \ldots \ldots \ldots \ldots\end{array}$ & $\begin{array}{l}118.0 \\
106.0\end{array}$ & $\begin{array}{l}116.0 \\
106.9\end{array}$ & $\begin{array}{l}116.3 \\
105.9\end{array}$ & $\begin{array}{l}2.0 ; 1.1 \\
-0.9 ; 0.4\end{array}$ & $\begin{array}{l}1.7 ; 0.6 \\
0.1 ; 0.0\end{array}$ & $\begin{array}{l}-0.3 ; 0.0 \\
1.0 ; 0.7\end{array}$ \\
\hline $\begin{array}{l}\text { Neck circumference, } m m . \\
\mathbf{M} \ldots \ldots \ldots \ldots \ldots \ldots \ldots \ldots \\
\mathrm{F} \ldots \ldots \ldots \ldots \ldots \ldots \ldots\end{array}$ & $\begin{array}{l}338.4 \\
317.9\end{array}$ & $\begin{array}{l}349.0 \\
329.3\end{array}$ & \begin{tabular}{|l|}
342.7 \\
324.3
\end{tabular} & $\begin{array}{l}-10.6 ; 2.6 \\
-11.4 ; 1.5\end{array}$ & $\begin{array}{l}-4.3 ; 0.6 \\
-6.4 ; 0.8\end{array}$ & $\begin{array}{l}6.3 ; 1.0 \\
5.0 ; 0.9\end{array}$ \\
\hline $\begin{array}{l}\text { Neck length, } \boldsymbol{m m} . \\
\mathbf{M} \ldots \ldots \ldots \ldots \ldots \ldots \ldots \\
\mathbf{F} \ldots \ldots \ldots \ldots \ldots \ldots\end{array}$ & $\begin{array}{l}119.0 \\
101.4\end{array}$ & $\begin{array}{r}105.9 \\
90.3\end{array}$ & $\begin{array}{r}108.4 \\
98.1\end{array}$ & $\begin{array}{l}13.1 ; 3.8 \\
11.1 ; 2.3\end{array}$ & $\begin{array}{l}10.6 ; 1.9 \\
3.3 ; 0.6\end{array}$ & $\begin{array}{l}-2.5 ; 0.4 \\
-7.8 ; 2.3\end{array}$ \\
\hline 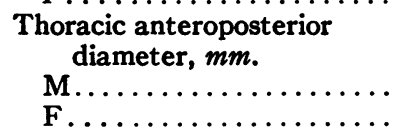 & $\begin{array}{l}195.4 \\
175.4\end{array}$ & $\begin{array}{l}215.9 \\
200.1\end{array}$ & $\begin{array}{l}203.8 \\
184.0\end{array}$ & $\begin{array}{l}-20.4 ; 4.5 \\
-24.7 ; 3.5\end{array}$ & $\begin{array}{l}-8.4 ; 1.3 \\
-8.6 ; 1.4\end{array}$ & $\begin{array}{l}12.0 ; 1.3 \\
16.1 ; 3.5\end{array}$ \\
\hline
\end{tabular}


TABLE v (continued)

\begin{tabular}{|c|c|c|c|c|c|c|}
\hline $\begin{array}{l}\text { Part } \\
\text { measured }\end{array}$ & $\begin{array}{l}\text { Arith- } \\
\text { metic } \\
\text { mean, } \\
\text { M1. } \\
\text { Peptic } \\
\text { ulcers }\end{array}$ & $\begin{array}{c}\text { Arith- } \\
\text { metic } \\
\text { mean, } \\
\text { Ms. } \\
\text { Dia- } \\
\text { betics }\end{array}$ & $\begin{array}{l}\text { Arith- } \\
\text { metic } \\
\text { mean. } \\
\text { Ma. } \\
\text { Chole- } \\
\text { cystitis }\end{array}$ & $\begin{array}{c}\text { Difference } \\
\text { between } \\
\mathbf{M}_{1} \text { and } \mathbf{M}_{2} \\
\mathbf{t}_{1 \rightarrow 3}\end{array}$ & $\begin{array}{c}\text { Difference } \\
\text { between } \\
\mathbf{M}_{1} \text { and } \mathbf{M}_{2} \\
\mathbf{t}_{1 \rightarrow}\end{array}$ & $\begin{array}{c}\text { Difference } \\
\text { between } \\
\mathbf{M}_{2} \text { and } \mathbf{M}_{2} \\
t_{2}\end{array}$ \\
\hline ic lateral diameter, $\mathrm{mm}$. & & & & & & \\
\hline 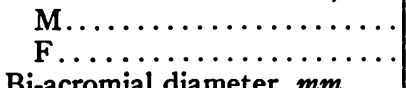 & $\begin{array}{l}265.8 \\
238.7\end{array}$ & $\begin{array}{l}280.4 \\
255.2\end{array}$ & $\begin{array}{l}273.0 \\
256.9\end{array}$ & $\begin{array}{l}-14.6 ; 2.8 \\
-16.5 ; 2.2\end{array}$ & $\begin{array}{l}-7.2 ; 1.0 \\
-18.2 ; 3.0\end{array}$ & $\begin{array}{l}7.4 ; 0.6 \\
-1.7 ; 0.3\end{array}$ \\
\hline $\begin{array}{l}\text { Bi-acromial diameter, } \boldsymbol{m} \boldsymbol{m} \text {. } \\
\quad \mathbf{M} \ldots \ldots \ldots \ldots \ldots \ldots \ldots \ldots \ldots \ldots \\
\mathbf{F} . \ldots \ldots \ldots \ldots \ldots \ldots \ldots\end{array}$ & $\begin{array}{l}380.4 \\
352.0\end{array}$ & $\begin{array}{l}386.8 \\
337.7\end{array}$ & $\begin{array}{l}374.7 \\
339.2\end{array}$ & $\begin{array}{l}-6.4 ; 1.2 \\
14.3 ; 2.5\end{array}$ & $\begin{array}{l}5.7 ; 0.6 \\
12.8 ; 2.2\end{array}$ & $\begin{array}{l}12.1 ; 1.2 \\
1.5 ; 0.4\end{array}$ \\
\hline $\begin{array}{l}\text { Thoracic circumference, } m m \text {. } \\
\quad \mathbf{M} . \ldots \ldots \ldots \ldots \ldots \ldots \ldots \ldots \\
\mathbf{F} \ldots \ldots \ldots \ldots \ldots \ldots \ldots\end{array}$ & $\begin{array}{l}818.0 \\
759.1\end{array}$ & $\begin{array}{l}869.0 \\
827.0\end{array}$ & $\begin{array}{l}868.8 \\
818.1\end{array}$ & $\begin{array}{l}-51.0 ; 3.6 \\
-67.9 ; 2.6\end{array}$ & $\begin{array}{l}-50.8 ; 2.9 \\
-59.0 ; 2.5\end{array}$ & $\begin{array}{l}0.2 ; 0.05 \\
8.9 ; 0.5\end{array}$ \\
\hline 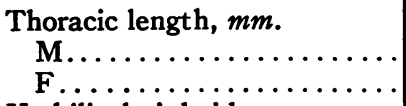 & $\begin{array}{l}181.5 \\
164.5\end{array}$ & $\begin{array}{l}177.9 \\
167.5\end{array}$ & $\begin{array}{l}190.0 \\
164.5\end{array}$ & $\begin{array}{l}3.5 ; 1.0 \\
-3.0 ; 0.5\end{array}$ & $\begin{array}{l}8.5 ; 1.5 \\
-0.0 ; 0.0\end{array}$ & $\begin{array}{l}12.1 ; 2.0 \\
3.0 ; 0.9\end{array}$ \\
\hline $\begin{array}{l}\text { Umbilical-xiphoid, } \boldsymbol{m m} \text {. } \\
\quad \mathbf{M} \ldots \ldots \ldots \ldots \ldots \ldots \ldots \ldots \ldots \ldots \ldots \ldots \ldots \ldots \ldots \ldots\end{array}$ & $\begin{array}{l}142.4 \\
155.0\end{array}$ & $\begin{array}{l}155.1 \\
169.8\end{array}$ & $\begin{array}{l}148.1 \\
158.2\end{array}$ & $\begin{array}{l}-12.7 ; 2.4 \\
-14.8 ; 1.5\end{array}$ & $\begin{array}{l}-5.7 ; 0.6 \\
-3.2 ; 0.3\end{array}$ & $\begin{array}{l}7.0 ; 0.7 \\
11.6 ; 1.6\end{array}$ \\
\hline $\begin{array}{l}\text { Umbilical-public, } m \boldsymbol{m} \text {. } \\
\quad \mathbf{M} \ldots \ldots \ldots \ldots \ldots \ldots \ldots \ldots \ldots \ldots \ldots \ldots \ldots \ldots\end{array}$ & $\begin{array}{l}144.8 \\
150.0\end{array}$ & $\begin{array}{l}144.2 \\
150.4\end{array}$ & $\begin{array}{l}140.6 \\
149.8\end{array}$ & $\begin{array}{l}0.6 ; 0.1 \\
-0.4 ; 0.7\end{array}$ & $\begin{array}{l}4.2 ; 0.6 \\
0.2 ; 0.0\end{array}$ & $\begin{array}{l}3.6 ; 0.5 \\
0.6 ; 0.1\end{array}$ \\
\hline $\begin{array}{l}\text { Bi-iliac diameter, } \boldsymbol{m m} \text {. } \\
\quad \mathbf{M} . \ldots \ldots \ldots \ldots \ldots \ldots \ldots \ldots \ldots \ldots \ldots \ldots \ldots\end{array}$ & $\begin{array}{l}233.2 \\
233.7\end{array}$ & $\begin{array}{l}241.4 \\
240.4\end{array}$ & $\begin{array}{l}234.1 \\
236.3\end{array}$ & $\begin{array}{l}-8.2 ; 1.7 \\
-6.7 ; 1.0\end{array}$ & $\begin{array}{l}-0.9 ; 0.1 \\
2.6 ; 0.5\end{array}$ & $\begin{array}{l}7.3 ; 1.2 \\
4.1 ; 1.0\end{array}$ \\
\hline $\begin{array}{l}\text { Nail length, } m m . \\
\quad \mathrm{M} . \ldots \ldots \ldots \ldots \ldots \ldots \ldots \\
\mathrm{F} . \ldots \ldots \ldots \ldots \ldots \ldots\end{array}$ & $\begin{array}{l}12.8 \\
10.7\end{array}$ & $\begin{array}{l}12.1 \\
10.7\end{array}$ & $\begin{array}{l}13.0 \\
10.2\end{array}$ & $\begin{array}{l}0.7 ; 1 \\
0 ; 0\end{array}$ & $\begin{array}{l}-0.2 ; 0.1 \\
0.5 ; 0.8\end{array}$ & $\begin{array}{l}-0.9 ; 1.0 \\
0.5: 1.3\end{array}$ \\
\hline Nail breadth, mm. & 10.1 & 10.1 & 10.2 & 0;0 & $0.5 ; 0.8$ & $0.0 ; 1.0$ \\
\hline 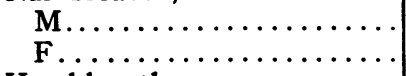 & $\begin{array}{l}16.2 \\
13.7\end{array}$ & $\begin{array}{l}15.0 \\
13.9\end{array}$ & $\begin{array}{l}16.3 \\
13.9\end{array}$ & $\begin{array}{l}1.2 ; 3.6 \\
-0.2 ; 0.4\end{array}$ & $\begin{array}{l}-0.1 ; 0.1 \\
-0.2 ; 0.4\end{array}$ & $\begin{array}{l}-1.3 ; 2.8 \\
0.0 ; 0.0\end{array}$ \\
\hline $\begin{array}{l}\text { Hand length, } \mathbf{m m} . \\
\quad \mathbf{M} \ldots \ldots \ldots \ldots \ldots\end{array}$ & 188.6 & 185.3 & 189.3 & 3.3 & $-0.7 ; 0.2$ & $-4.0 ; 1.2$ \\
\hline Hand breadth, $m m$. & 172.5 & 169.7 & 168.2 & $2.8 ; 0.9$ & $4.2 ; 1.5$ & $1.4 ; 0.8$ \\
\hline$\cdots \ldots \ldots \ldots \ldots \ldots \ldots$ & $\begin{array}{l}82.2 \\
74.1\end{array}$ & $\begin{array}{l}80.7 \\
73.5\end{array}$ & $\begin{array}{l}81.8 \\
71.7\end{array}$ & $\begin{array}{l}1.5 ; 1.2 \\
0.6 ; 0.4\end{array}$ & $\begin{array}{l}0.4 ; 0.1 \\
2.4 ; 1.7\end{array}$ & $\begin{array}{l}-1.1 ; 0.5 \\
1.8 ; 2.0\end{array}$ \\
\hline Finger circumference, $\mathrm{mm}$. & 60.0 & 60.5 & 62.0 & $-0.5 ; 0.5$ & $-2.0 ; 1.2$ & $-1.5 ; 1.0$ \\
\hline Leg circumference, $m m$. & 54.8 & 56.1 & 54.6 & $-1.3 ; 0.7$ & $0.2 ; 0.1$ & $1.5 ; 1.4$ \\
\hline $\mathbf{M} \ldots \ldots \ldots \ldots \ldots \ldots$ & 289.3 & 302.2 & 299.3 & $-12.9 ; 2.2$ & $-10.0 ; 1.0$ & $2.9 ; 0.3$ \\
\hline F........................ & 290.8 & 294.4 & 301.6 & $-3.6 ; 0.3$ & $-10.8 ; 1.1$ & $-7.2 ; 1.0$ \\
\hline $\begin{array}{l}\text { Humerus, } m m \text {. } \\
\text { M.......... }\end{array}$ & 301.0 & 301.6 & 308.5 & $-0.6 ; 0.1$ & $-7.5 ; 1.0$ & $-6.9 ; 0.9$ \\
\hline $\begin{array}{r}F \\
\text { Radius, } m m\end{array}$ & 281.3 & 279.7 & 277.2 & $1.6 ; 0.2$ & $4.1 ; 0.7$ & $2.5 ; 0.6$ \\
\hline $\mathbf{M} \ldots \ldots \ldots \ldots$ & $\begin{array}{l}261.6 \\
233.1\end{array}$ & $\begin{array}{l}256.6 \\
232.3\end{array}$ & $\begin{array}{l}255.0 \\
225.1\end{array}$ & $\begin{array}{l}5.0 ; 1.1 \\
0.8 ; 0.1\end{array}$ & $\begin{array}{l}6.6 ; 0.9 \\
8.0 ; 1.4\end{array}$ & $\begin{array}{l}1.6 ; 0.2 \\
7.2 ; 2.0\end{array}$ \\
\hline $\begin{array}{l}\text { Arm length, mm. } \\
\quad \text { M............... }\end{array}$ & $\begin{array}{l}748.2 \\
677.7\end{array}$ & $\begin{array}{l}739.5 \\
672.3\end{array}$ & $\begin{array}{l}753.3 \\
663.3\end{array}$ & $\begin{array}{l}8.7 ; 1.1 \\
5.4 ; 0.4\end{array}$ & $\begin{array}{l}-4.9 ; 0.4 \\
14.4 ; 1.2\end{array}$ & $\begin{array}{l}-13.8 ; 0.8 \\
9.0 ; 1.1\end{array}$ \\
\hline $\begin{array}{l}\text { Femur, } \boldsymbol{m m} . \\
\quad \mathbf{M} \ldots \ldots \ldots \ldots \\
\text { F. } \ldots \ldots \ldots\end{array}$ & $\begin{array}{l}406.1 \\
388.1\end{array}$ & $\begin{array}{l}397.1 \\
376.9\end{array}$ & $\begin{array}{l}416.4 \\
370.0\end{array}$ & $\begin{array}{l}9.0 ; 1.4 \\
11.2 ; 1.1\end{array}$ & $\begin{array}{l}-10.3 ; 1.0 \\
18.1 ; 1.8\end{array}$ & $\begin{array}{l}-19.3 ; 1.8 \\
6.9 ; 1.0\end{array}$ \\
\hline
\end{tabular}


TABLE V (continued)

\begin{tabular}{|c|c|c|c|c|c|c|}
\hline $\begin{array}{c}\text { Part } \\
\text { measured }\end{array}$ & $\begin{array}{l}\text { Arith- } \\
\text { metic } \\
\text { mean, } \\
\text { M1. } \\
\text { Peptic } \\
\text { ulcers }\end{array}$ & $\begin{array}{c}\text { Arith- } \\
\text { metic } \\
\text { mean, } \\
\text { M2. } \\
\text { Dia- } \\
\text { betics }\end{array}$ & $\begin{array}{l}\text { Arith- } \\
\text { metic } \\
\text { mean, } \\
\text { Ma: } \\
\text { Chole- } \\
\text { cystitis }\end{array}$ & $\begin{array}{c}\text { Difference } \\
\text { between } \\
\mathbf{M}_{1} \text { and } \mathbf{M}_{2} \\
\mathrm{t}_{1-2}\end{array}$ & $\begin{array}{c}\text { Difference } \\
\text { between } \\
\mathbf{M}_{1} \text { and } \mathbf{M}_{2} \\
\mathbf{t}_{1 \rightarrow 3}\end{array}$ & $\begin{array}{l}\text { Difference } \\
\text { between } \\
\mathbf{M}_{2} \text { and } \mathbf{M}_{2} \\
t_{2-3}\end{array}$ \\
\hline$m m$. & & & & & & \\
\hline $\begin{array}{l}\mathbf{M} \ldots \ldots \ldots \ldots \ldots \\
\mathbf{F} \ldots \ldots \ldots \ldots\end{array}$ & $\begin{array}{l}398.5 \\
370.4\end{array}$ & $\begin{array}{l}389.5 \\
360.6\end{array}$ & $\begin{array}{l}405.7 \\
352.1\end{array}$ & 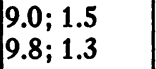 & $\begin{array}{l}-7.2 ; 0.7 \\
18.3 ; 2.1\end{array}$ & $\begin{array}{l}-16.2 ; 1.4 \\
8.5 ; 1.5\end{array}$ \\
\hline Total leg length, $\mathrm{mm}$ & & & & & & \\
\hline $\begin{array}{l}\mathbf{M} \\
\mathrm{F} \\
\ldots \ldots \ldots \ldots \ldots \ldots \ldots \ldots \ldots \ldots \ldots\end{array}$ & $\begin{array}{l}877.3 \\
813.6\end{array}$ & $\begin{array}{l}864.1 \\
800.0\end{array}$ & $\begin{array}{l}898.5 \\
785.1\end{array}$ & $\begin{array}{l}13.2 ; 1.2 \\
13.6 ; 0.8\end{array}$ & $\begin{array}{l}-21.2 ; 1.2 \\
28.5 ; 1.7\end{array}$ & $\begin{array}{l}-34.4 ; 1.7 \\
14.9 ; 1.4\end{array}$ \\
\hline $\begin{array}{l}\text { Foot height, } m m . \\
\text { M................ }\end{array}$ & 72.4 & 77.6 & 76.4 & $-5.2 ; 1.1$ & $-4.0 ; 0.5$ & $1.2 ; 0.1$ \\
\hline 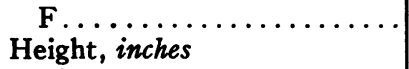 & 55.0 & 62.3 & 64.6 & $-7.3 ; 9.9$ & $-9.6 ; 1.2$ & $-2.3 ; 0.4$ \\
\hline $\mathbf{M} \ldots \ldots \ldots \ldots \ldots \ldots$ & 65.7 & 66.4 & 68.1 & $-0.7 ; 0.9$ & $-2.4 ; 1.9$ & $-1.7 ; 1.2$ \\
\hline$\underset{\text { Weight, pounds }}{F} \ldots \ldots \ldots \ldots \cdots \cdots$ & 61.5 & 60.9 & 60.6 & $0.6 ; 0.6$ & $0.9 ; 0.8$ & $0.3 ; 0.4$ \\
\hline 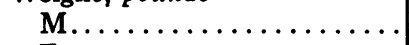 & 128.4 & 147.0 & 146.6 & $-18.6 ; 3.9$ & $-18.2 ; 2.4$ & $0.4 ; 0.3$ \\
\hline Upper facial index ${ }_{\text {Up }}^{*} \cdots \cdots \cdots$ & 125.6 & 136.9 & 138.6 & $-11.3 ; 1.0$ & $-13.0 ; 1.5$ & $-1.7 ; 0.2$ \\
\hline 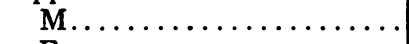 & 63.7 & 60.3 & 58.9 & $3.4 ; 1.8$ & $4.8 ; 2.3$ & $1.4 ; 0.3$ \\
\hline Lower facial index, $\dagger$ & 61.8 & 58.5 & 61.0 & $3.3 ; 1.9$ & $0.8 ; 0.3$ & $-2.5 ; 2.1$ \\
\hline 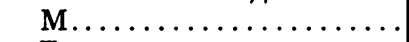 & 112.6 & 107.3 & 104.1 & $5.3 ; 2.3$ & $8.5 ; 2.6$ & $3.2 ; 0.9$ \\
\hline$\underset{\text { Neck index } \ddagger}{F} \ldots \ldots \ldots \ldots \ldots$ & 107.7 & 104.1 & 104.4 & $3.6 ; 1.6$ & $3.3 ; 1.2$ & $-0.3 ; 0.1$ \\
\hline$M \ldots \ldots \ldots \ldots \ldots \ldots$ & 35.2 & 30.6 & 31.7 & $4.6 ; 4.3$ & $3.5 ; 2.1$ & $-1.1 ; 0.6$ \\
\hline Thoracic index 18 & 32.2 & 27.6 & 30.5 & $4.6 ; 2.6$ & $1.7 ; 8.3$ & $-2.9 ; 2.3$ \\
\hline M............ & 73.8 & 77.4 & 75.6 & $-3.6 ; 2.4$ & $-1.8 ; 0.6$ & $1.8 ; 0.5$ \\
\hline Thoracic index II $\| \cdots \cdots$ & 73.3 & 78.7 & 71.7 & $-5.4 ; 1.9$ & $1.6 ; 0.8$ & $7.0 ; 4.1$ \\
\hline $\mathbf{M} \ldots \ldots \ldots \ldots$ & 22.2 & 20.7 & 21.9 & $1.5 ; 2.7$ & $0.3 ; 0.3$ & $-1.2 ; 1.1$ \\
\hline F $\ldots \ldots \ldots$ & 21.7 & 20.4 & 20.3 & $1.3 ; 2.0$ & $1.4 ; 2.3$ & $0.1 ; 0.2$ \\
\hline Umbilical index $\mathbb{T}$ & & & & & & \\
\hline M......... & 103.9 & 94.3 & 96.8 & $9.6 ; 2.1$ & $7.1 ; 0.9$ & $-2.5 ; 0.4$ \\
\hline $\begin{array}{c}F \ldots \ldots \ldots \ldots \\
\text { Arm leg index }\end{array}$ & 97.7 & 90.8 & 97.3 & $6.9 ; 1.2$ & $0.4 ; 0.0$ & $-6.5 ; 1.5$ \\
\hline $\mathbf{M} \ldots \ldots \ldots$ & 85.4 & 85.4 & 83.0 & $0 ; 0$ & $2.4 ; 2.0$ & $2.4 ; 2.4$ \\
\hline$F \ldots \ldots \ldots$ & 83.5 & 84.1 & 84.5 & $-0.6 ; 0.7$ & $-1.0 ; 0.9$ & $-0.4 ; 0.6$ \\
\hline Ponderal index $\dagger^{\dagger}$ & & & & & & \\
\hline M... & 19.5 & 22.2 & 21.5 & $-2.7 ; 3.6$ & $-2.0 ; 1.6$ & $0.7 ; 0.4$ \\
\hline F... & 21.0 & 22.6 & 22.8 & $-1.6 ; 0.9$ & $-1.8 ; 1.2$ & $-0.2 ; 0.2$ \\
\hline
\end{tabular}

M.-male.

F.-female.

* Nasion prosthion

Facial diameter

+ Nasion submenton

Bigonial diameter

$\ddagger$ Neck height

Neck circumference

$\S$ Thoracic anteroposterior diameter.

Thoracic lateral diameter

$\|$ Thoracic length

Thoracic circumference.

IUmbilicus-pubis

Umbilicus-xyphoid

** Arm length

Leg length.

t+ Weight

Height 
the male and female peptic ulcer and cholecystitis groups. Both sets of figures show an increased circumference in the cholecystitis patients. The chest circumference of diabetic males and females also exceeds that of peptic ulcer patients.

In the present series the female peptic ulcer patients showed a larger tibial length than did the cholecystitis patients, whereas Draper's figures tended to show the reverse. Here again the distance measured lay between bony points, so that the absence of similar results suggests that the relationship cannot be a constant nor an important one.

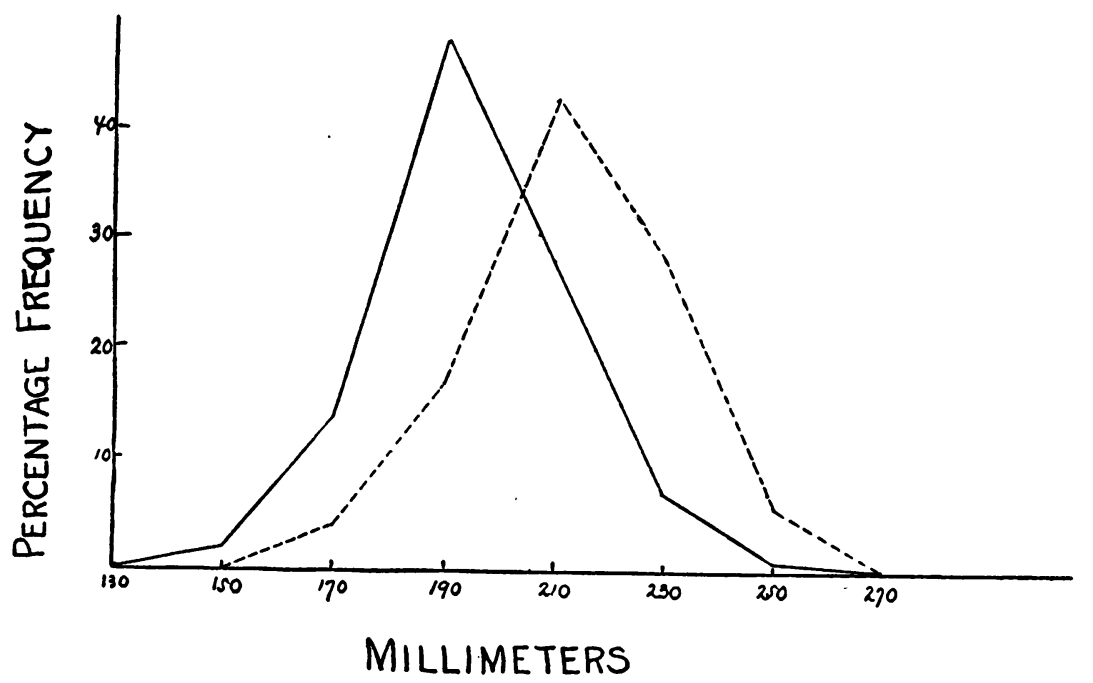

Fig. 5

Thoracic anteroposterior diameter (male). Peptic ulcer cases 55; - - - Diabetic cases 27. Note the relatively smooth contour of the curves. There is a considerable degree of overlapping, though ' $t$ ' is 4.5.

The cholecystitis patients in this and Draper's series weighed more than the peptic ulcer cases, a confirmation of an old and a well tried observation. However, it was only in comparing the weight of the male cholecystitis with the male ulcer patients, that the difference was found to be significant.

\section{DISCUSSION}

In the last 10 years, many papers have appeared in the literature calling attention to the fact that constitution and disease are interrelated, in the anatomical as well as in the other panels. It is to Draper (5) that we owe the renewed interest in this subject on this continent. Our results do not bear out Draper's conclusions however. The material incorporated in Draper's book "Human Constitution" (5) was drawn from 6 disease groups, namely, peptic ulcer, cholecystitis, pernicious anemia, nephritis with 
hypertension, pulmonary tuberculosis, and asthma. The material for the present paper consists of three groups as already seen. Of these, only two were the same as Draper's, and generally, as the following illustrative examples show, our results do not corroborate Draper's conclusions. Thus, the large mandible found by Draper in the male ulcer cases was not present in this series. The dolichocephalic trend did not occur in the ulcer patients of this series, neither did the long, broad ears in the cholecystitis cases. Although the upper facial diameter was slightly longer in the male cholecystitis patients than in the others in both investigations, the difference was too small to be important. The increased neck height of the peptic ulcer race has already been alluded to and was common to both series of patients. The observation that the gallbladder patients show the thickest chests has been confirmed, as has been also the increased chest circumference of these individuals. In a small number of instances then, the trend of the figures in the two series is comparable, but there is in general strikingly little to encourage the student of constitution in the belief that anatomical features are important elements in the etiology of disease. Moreover, a good many students interested in the relation between constitution and disease have been disappointed at the relatively fruitless results of work in this field. Stockard (8) has expressed such an opinion after critically surveying the work which has been done. Udaondo (9), from a wide clinical experience, has concluded that there is no specific type associated with peptic ulcer. Levine, Neal and Park (7), found no relationship between body type in children and predisposition to the development of poliomyelitis. These investigators employed anthropometric methods in 52 patients who had contracted poliomyelitis. These were contrasted with 52 normal controls of the same age and race.

In addition to the material issuing from Draper's laboratory, there have been other contributions supporting his point of view. Barach (3) has described clinical types which he believes are distinct both for males and females, and which are particularly predisposed to the development of hypertension later in life. Anatomical types such as Barach has indicated undoubtedly exist, but it is difficult to link them always with the development of hypertension.

In recent years there has been much speculation as to the importance of constitutional predisposition in the etiology of both exophthalmic goitre and toxic adenoma of the thyroid gland. It has been suggested by many students that of the several factors involved in the production of a toxic goitre, the fundamental one is the individual's constitution. On this basis various anatomical peculiarities have been attributed to the Graves' constitution. Warthin (11) pointed out that Graves' constitution could be recognized histologically by the presence of embryonic lymph follicles in the thyroid tissue. He suggested that these constituted the substratum for the production of goitre, though there must occur coincidentally an altered 
functional reaction in the individual. However, so far as can be determined, anthropometric methods have not been applied to the study of constitution in goitre, so that the anatomical type in this disease still remains theoretical.

If constitution is one of the determinants in the incidence of disease, its importance should be as obvious in pediatrics as it is in the diseases of adults. With this in mind the Bakwins (2) studied the body build of infants affected with intestinal intoxication, eczema and tetany as compared with a normal group. In the first of these groups they found that the bigonial diameter and the thoracic circumference were reduced as compared with a normal group. The reverse relationship applied in the series with

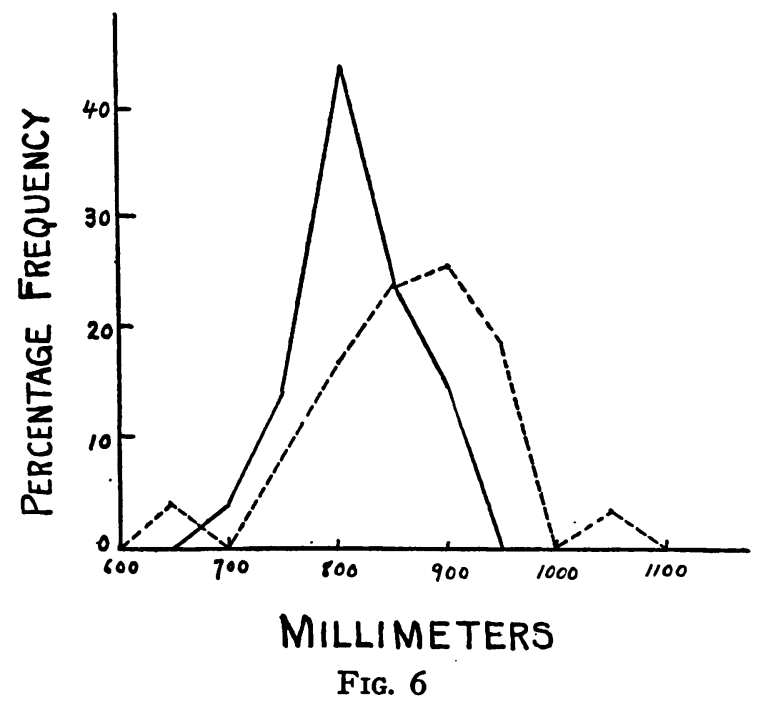

Chest circumference (male). Peptic ulcer cases 55;

Diabetic cases 27 . Note the disparity between the peak of the diabetic and the peptic ulcer patients. This is borne out by ' $t$ ' which is 3.6.

eczema and tetany. This work has been carefully done and deserves attention. But the following objection may be raised here. Only four body measurements were compared in the four groups. Therefore one cannot conclude from their results that the relationship between physical types and disease incidence has been proven.

It had been suggested years ago that the size of organs or of systems might determine their predisposition to disease. Brown (4) has attempted to settle this aspect of the problem in the laboratory. He believes that there are two phases of organic constitution which should be considered, namely, the organ-body-weight relation or organ balance, and the organ equilibrium or interrelation of organs. The basic ratio of these states differs in individuals by virtue of heredity. They may vary from month 
to month and from year to year because of environmental influences. There is, however, in this connection a normal trend. In summer there is a tendency towards a high positive organ balance due to a predominant endocrine influence (?), while in winter this condition is reversed. During the periods of transition, Brown believes the animal or the human body to be in a state susceptible to disease. While this author has been able to prove the lability of the organ to body and organ to organ relation, he has not been able to prove that these changes are correlated with the development of disease.

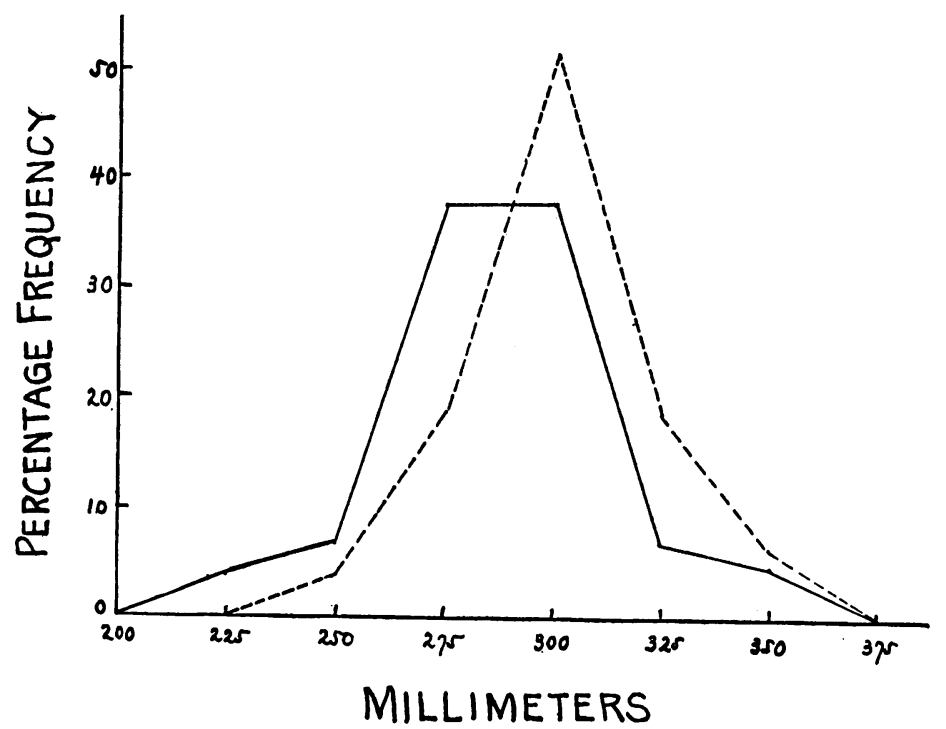

FIG. 7

Leg circumference (male). Peptic ulcer cases 55 Diabetic cases 27. Note again the flat top of the peptic ulcer group. The area which overlaps in the two curves is rather small.

\section{SUMMARY AND CONCLUSIONS}

The question whether physical constitution affects the incidence of disease in the average patient is as old as the scientific study of disease. The evolution of interest in constitution has proceeded along the following lines. Physical form and function were first related to each other by anatomists and physiologists. Then anatomical form and pathological function were linked by the old clinicians and pathologists. However, the only scientific proof for such an association lay in clinical impressions until the recent introduction of anthropometric methods to this problem by di Giovanni (15), Beneke (14), and Draper (5).

The material upon which this paper is based consists of 192 patients in 3 disease groups; 79 patients with diabetes mellitus, 67 with peptic ulcer, 
and 46 with cholecystitis. The chief difficulties met with in the work are threefold. In the first place, anatomical features which may be predisposing factors to disease, must be distinguished from the anatomical effects of disease upon the body. Secondly, the racial distribution of the patients must be considered. The three groups studied showed practically an equal distribution for the various races. And thirdly, there should be a sufficiently large number of cases in each disease group to make the results of statistical treatment reliable. There was an adequate number in all the groups except in the male cholecystitis and female peptic ulcer patients. In both of the latter, the difficulty produced by small numbers was obviated by suitable mathematical methods. Thirty-seven measurements were taken on each patient, in addition to a record of the condition of the skin and its appendages.

In the final analysis of the results, the value of " $t$ " was obtained and considered. This letter is the ratio between the difference of two means, and the standard error of the difference. When " $t$ " equals or exceeds 2 , it is assumed, by statisticians, to be significant. Out of 270 cases in which " $t$ " was obtained, it reached a significant value in 53 instances, or 19 per cent. But, the difference pointed in the same direction for both the male and female patients in only 9 measurements, in the following cases. The bigonial diameter, the thoracic anteroposterior diameter, the thoracic lateral diameter, the thoracic circumference and the thoracic index $1^{2}$ were all greater in the diabetic than in the peptic ulcer patients. The neck height of the peptic ulcer patients exceeded that of the diabetics. The neck index and the thoracic index II $^{8}$ were larger in the peptic ulcer than in the diabetic patients. The thoracic circumference of the cholecystitis males and females was larger than that of the peptic ulcers. In the remaining cases in which differences were found, they occurred in only one or other of the sexes.

Because of the inconclusive opinions expressed in the literature, and the work presented here, it is thought that, in the past, too much stress has been placed upon the importance of physical constitution in the etiology of disease. At present there is no basis for employing it in diagnosis or in the selection of individuals who will be predisposed to diabetes mellitus, peptic ulcer and cholecystitis.

It is due largely to Dr. Jonathan C. Meakins, Professor of Medicine, McGill University, that this investigation has been made possible. In addition, Dr. Meakins has given constant counsel and encouragement. It is a pleasure also to acknowledge the interest of Dr. Edward W. Archibald,

\footnotetext{
2 Thoracic anteroposterior diameter. Thoracic length

3 Thoracic length

Thoracic circumference
} 
Professor of Surgery, McGill University, and of his colleagues from whose wards a large number of the patients were drawn. We are indebted to Dr. Edward H. Mason for providing a number of cases from his ward. Miss Helen Stevenson rendered valuable assistance with the anthropologic measurements.

\section{BIBLIOGRAPHY}

1. Avicenna, A Treatise on the Canon of Medicine of Avicenna. Translated by O. C. Gruner, Luzac and Co., London, 1930.

2. Bakwin, H., and Bakwin, Ruth M., Body build in infants. I. The technique of measuring the external dimensions of the body in infants. II. The proportions of the external dimensions of the healthy infant during the first year of life. III. Body build in disease. J. Clin. Invest., 1931, 10, 369, 377 and 395.

3. Barach, J. H., The constitutional factors in hypertensive disease. J. A. M. A., 1928, 91, 1511.

4. Brown, W. H., Constitutional variation and susceptibility to disease. Arch. Int. Med., 1929, 44, 625.

5. Draper, George, Human constitution, a consideration of its relationship to disease. W. B. Saunders, Philadelphia, 1924.

Draper, G., Dunn, H. L., and Seegal, D., Studies in human constitution: Facial form and disease correlation. Am. J. M. Sc., 1925, 169, 322.

Draper, G., Allen, Grace, and Spock, Jane C., Studies in human constitution. VI. Clinical genetics. J. A. M. A., 1929, 92, 2149.

Draper, G., and Touraine, G. A., The man-environment unit and peptic ulcer. Arch. Int. Med., 1932, 49, 616.

6. Hutchinson, Jonathan, The pedigree of disease. Churchill, London, 1884.

7. Levine, M. I., Neal, J. B., and Park, W. H., Relation of physical characteristics to susceptibility to anterior poliomyelitis. J. A. M. A., 1933, 100, 160.

8. Stockard, C. R., Constitution and type in relation to disease. Medicine, 1926, $5,105$.

9. Udaondo, C. B., Les Ulcères de l'Estomac et l'état Constitutionnel. Arch. de mal. de l'app. digestif., 1928, 18, 841 .

10. Walkington, I., The Optick Glasse of Humors, 1663.

11. Warthin, A. S., The constitutional entity of exophthalmic goiter and socalled toxic adenoma. Ann. Int. Med., 1928, 2, 553.

12. Bauer, J., Die Konstitutionelle Disposition zu Innern Krankheiten. Berlin, 1921.

13. Kretschmer, L., Körperbau und Character. Berlin, 1921.

14. Beneke, F. W., Die alterdisposition. Warburg, 1879.

15. di Giovanni, A., Clinical commentaries deduced from the morphology of the human body (English edition). London, 1919. 